Abstracta Iranica Iranica

Revue bibliographique pour le domaine irano-aryen

Volume 25 | 2004

Comptes rendus des publications de 2002

\title{
« Musique et Musiciens d'Ouzbékistan ». Missives, (2001), pp. 62-73.
}

\section{Rédaction}

\section{(2) OpenEdition}

1 Journals

\section{Édition électronique}

URL : http://journals.openedition.org/abstractairanica/5274

DOI : 10.4000/abstractairanica.5274

ISSN : 1961-960X

Éditeur :

CNRS (UMR 7528 Mondes iraniens et indiens), Éditions de l'IFRI

\section{Édition imprimée}

Date de publication : 15 mai 2004

ISSN : 0240-8910

Référence électronique

Rédaction, « « Musique et Musiciens d'Ouzbékistan ». Missives, (2001), pp. 62-73. », Abstracta Iranica [En ligne], Volume 25 | 2004, document 373, mis en ligne le 15 mars 2006, consulté le 25 septembre 2020. URL : http://journals.openedition.org/abstractairanica/5274 ; DOI : https://doi.org/10.4000/ abstractairanica. 5274

Ce document a été généré automatiquement le 25 septembre 2020.

Tous droits réservés 
« Musique et Musiciens d'Ouzbékistan ». Missives, (2001), pp. 62-73.

\section{Rédaction}

1 Dans une première partie, est posé le décor de la vie musicale en Ouzbékistan, avec ses particularités uniques telles que son instrumentalisation à des fins nationalistes, contre-balancé par son ancrage dans la sphère privée par l'institution sociale du toy (fête). Dans la seconde partie, comme pour marquer le contraste, est tracé le portrait d'un fameux barde représentant typique de la culture nomade, versant mal connu de l'identité ouzbèke.

INDEX

Thèmes : 17.1.Musique

\section{AUTEURS}

\section{RÉDACTION}

Directeur de la revue et secrétariats (Paris et Téhéran) 